\title{
Engineering Geological Characteristics Based on Rock Mass Rating (RMR) and Geological Strength Index (GSI) in Jlantah Dam Intake Tunnel, Karanganyar District, Central Java Province
}

\author{
Doni Apriadi Putera ${ }^{1}$, Heru Hendrayana ${ }^{1}$ and I Gde Budi Indrawan ${ }^{1 *}$ \\ ${ }^{1}$ Geological Engineering Departement, Engineering Faculty, Gadjah Mada University, Sleman, Yogyakarta, Indonesia
}

\begin{abstract}
This paper presents the results of a geological engineering investigation in the form of rock mass characterization at the Jlantah Dam Intake Tunnel. The study was carried out through technical geological mapping, core drill evaluation and supported by laboratory test data. The determination of rock mass classification at the research site has been carried out using the Rock Mass Rating (RMR) method, but it is necessary to use another method that is more suitable based on rock mass for weak rocks, namely using the Geological Strength Index (GSI) method.The rock mass quality will be used as a parameter in determining the excavation method and tunnel support system that will be used in the Jlantah Dam intake tunnel. The results showed that the research area consisted of lithology in volcanic breccias and tuff lapilli. GSI rock mass value at the research location ranged from 15 - 65, while the RMR value ranged from $24-70$. The correlation between RMR and GSI in the study area is different when compared to Hoek and Brown (1997) but has similarities with Zhang et al (2019).
\end{abstract}

\section{Introduction}

The research location is at the Jlantah Dam construction site. Administratively, this dam is located in Tlobo Village, Jatiyoso District, Karanganyar Regency, Central Java Province (Figure 1).

Several site investigations have been carried out in the design stage of the Jlantah Dam construction [8]. Still, the study of rock mass characterization in the intake tunnel was not carried out in detail. A detailed description of rock mass needs to be carried out for the tunnel's safety because the characteristics of the rock mass influence the stability of the portal slope, the determination of the excavation method, and the tunnel support system.

The determination of rock mass classification at the research location has been carried out using the Rock Mass Rating (RMR) method, while the rocks at the study site are lapilli tuff rocks in moderately weathered conditions. Determination of rock mass classification should be made based on rock mass classification for weak rocks, for example by applying the Geological Strength Index (GSI) [7], in order to obtain an appropriate rock support system.

\section{Regional Geology}

Based on the Geological Map of the Ponorogo Sheet compiled by Sampurno and Samudro [10] , the rock formations that contain the tunnel location and its surroundings consist of Lava Lawu (Ella) Jobolarang Lava (Qvjl), and Lava Sidoramping (Qvsl) formations (Figure 2). Mapping in the field resulted in the four rock and soil units that make up the research area. The four rock and soil units from old to young are: Volcanic Breccia Unit, Slightly and Moderately weathered Lapilli Tuff Unit and Silt Sand Soil Unit. The rock units in the research area are included in the Lawu Volcano sediment with a Holocene age.

From the results of the surface geological mapping that has been carried out along the Jlantah River and the Puru River, starting from the plan of the Jlantah Dam to the inundation plan area, it is known that the regional geological structure pattern covering the investigation area has a west-east straight line and is not a fault. The local geological structures found are the stocky structure of the breccias and poor bedding on the breccias sandstone insert.

\section{Methodology}

The main reason for using RMR is its ease and flexibility in various practical purposes in engineering [2]. According to Bieniawski [2], the rock mass classification of the RMR method uses 6 (six) parameters with 
measurements that can be carried out in the field and interpretation of drill hole data. These parameters include 1) Uniaxial Compressive Strength (UCS) of intact rock material, 2) Rock Quality Designation (RQD), 3) discontinuity spacing, 4) discontinuity conditions, 5) groundwater conditions, and 6) discontinuity orientation. The rock mass quality parameters are used to determine the RMR value at the research site based on Bieniawski [2].

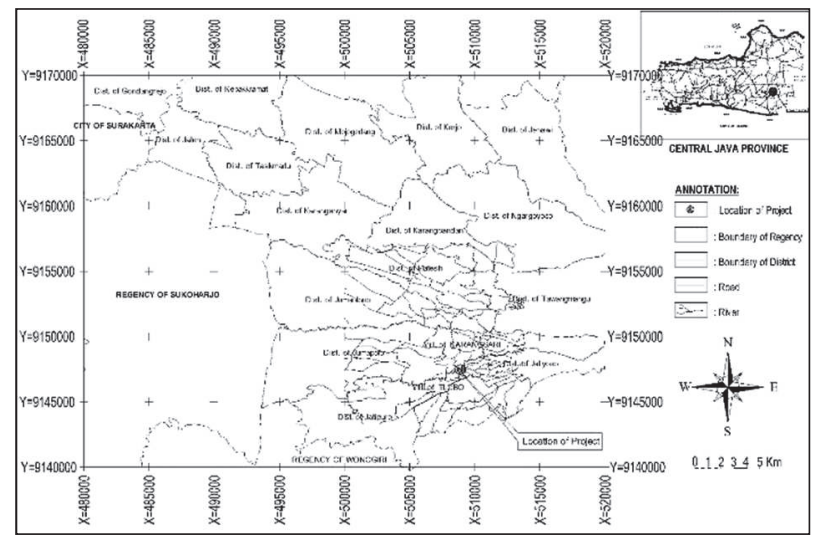

Fig. 1. Location of Jlantah Dam intake tunnel

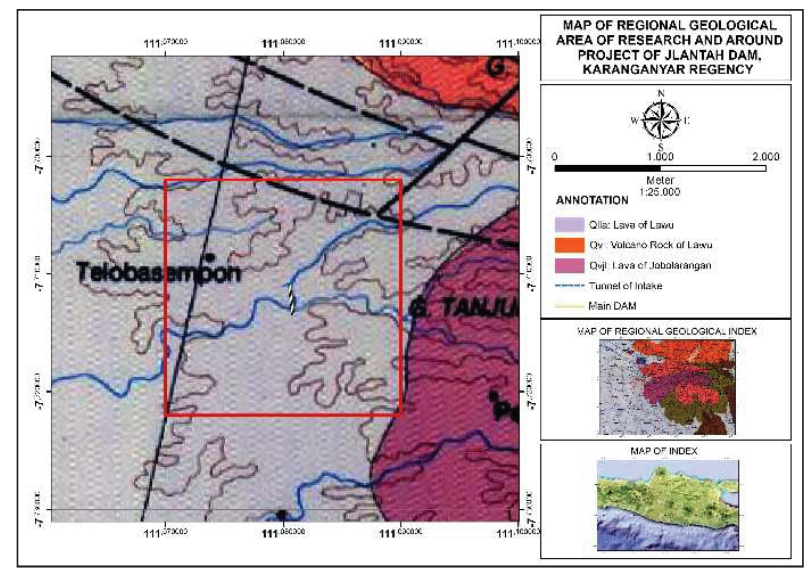

Fig. 2. Regional geological map around the jlantah dam

The GSI introduced by Hoek and Marinos [7] provides figures which, when combined with intact rock properties, can be used to estimate the reduction in rock mass strength for different geological conditions. In subsequent developments, GSI is incorporated into two main parameters, namely the structure of the block properties and surface conditions in the form of roughness, weathering, or alteration and fill as described by Hoek at al [5]. According to Hoek et al. [5], to calculate the subsurface GSI value using the formula:

$$
\text { GSI=1.5 JCond } 89+\mathrm{RQD} / 2 \quad \text { (1) }
$$

The Jcon (joint condition) value in equation (1) refers to the classification of the common disease according to Bieniawski [2].
The rock mass classification using the GSI system is an extension of the rock mass classification of the RMR system. The parameters used for GSI are generally based on RMR. Research on the correlation between RMR and GSI has been carried out by several researchers, namely Hoek and Brown [4], Ceballos and Olalla [3] and Zhang et al [11]. The $\mathrm{RMR}_{89}$ value is the basic RMR value [2] by providing a groundwater value with a weight of 15 (dry conditions) and a common orientation value with a weight of 0 (zero). The minimum value for the rock mass classification of RMR 1989 is 23. Hoek and Brown [4] explain that rock mass with GSI $>25$ and RMR $>23$, the GSI value can be calculated by the following Equation (2):

$$
\text { GSI }=\mathrm{RMR}_{89}-5
$$

Zhang et al [11] investigated the correlation of RMR with GSI at the surface of the tunnel excavation and produced equation (3)

$$
\mathrm{RMR}_{89}=0.827 \mathrm{GSI}+15.394
$$

Ceballos and Olalla [3] examined the correlation between RMR and GSI based on the rock types, namely igneous, metamorphic and sedimentary rocks and based on outcrops, namely natural, mining and excavated for road project work. The resulting equation in general is as follows:

$$
\mathrm{GSI}=1.13 \mathrm{RMR}-11.63
$$

\section{Results and Discussion}

Observations of rock outcrops indicate that the research area consists of 4 rock units from old to young, namely: Volcanic Breccia Unit, Slightly and Moderately weathered Lapilli Tuff Unit, and Silt Sand Soil Unit. The map of the distribution of rock units and the geological cross-section of the research location can be seen in Figures 3 and 4. Examples of outcrops of lapilli tuff and volcanic breccias are shown in Figures 5 and 6. The path of the intake tunnel is located in the Tuff Lapilli Unit.

Based on subsurface data (core drill, Fig. 7), the rock mass classification in the research area has rock discontinuity with high to slightly weathering rates. The GSI value of rock mass in the research area ranges from 15 - 65, while the RMR value ranges from $24-70$. The relationship between the GSI value and the rock mass RMR in the research area can be expressed by the following equation (Figure 8):

$$
\mathrm{RMR}=0.827 \mathrm{GSI}+14.493
$$




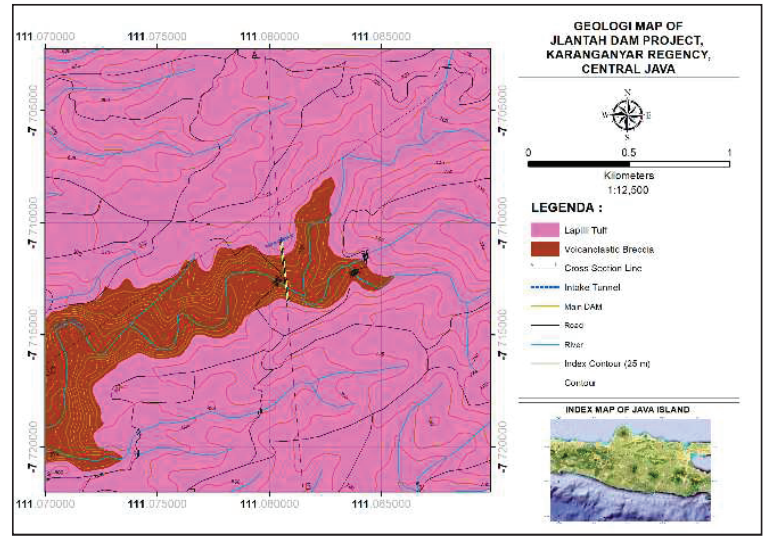

Fig. 3. Geological map of the research area

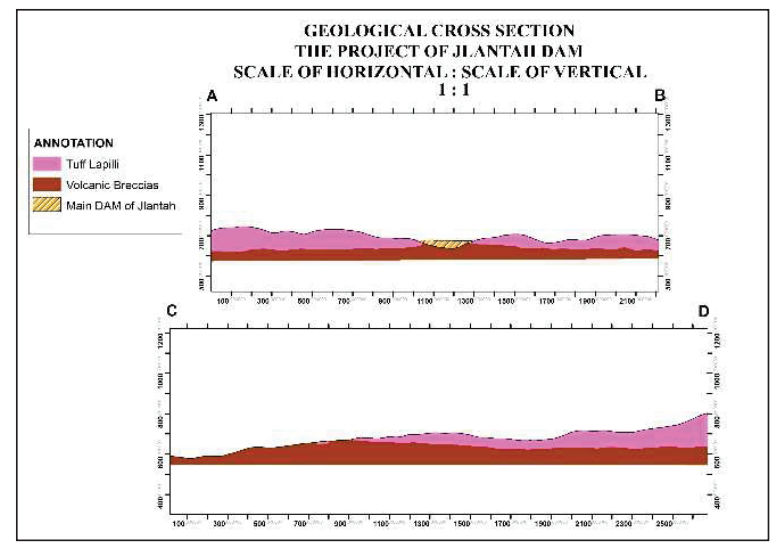

Fig. 4. Geological cross section of Jlantah dam

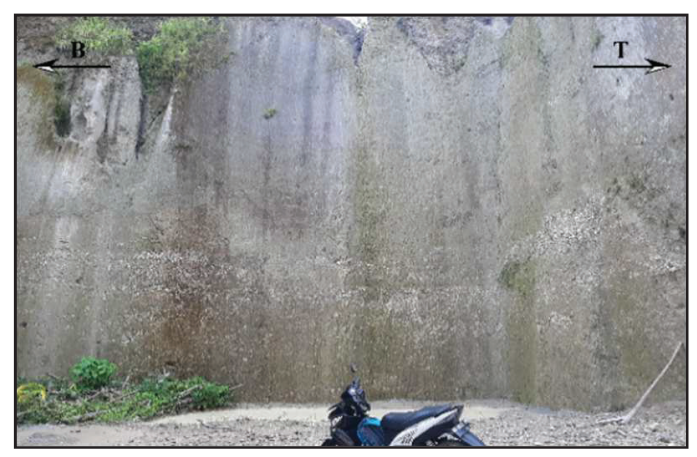

Fig. 5. Outcrop of Lapilli tuf slightly weathered

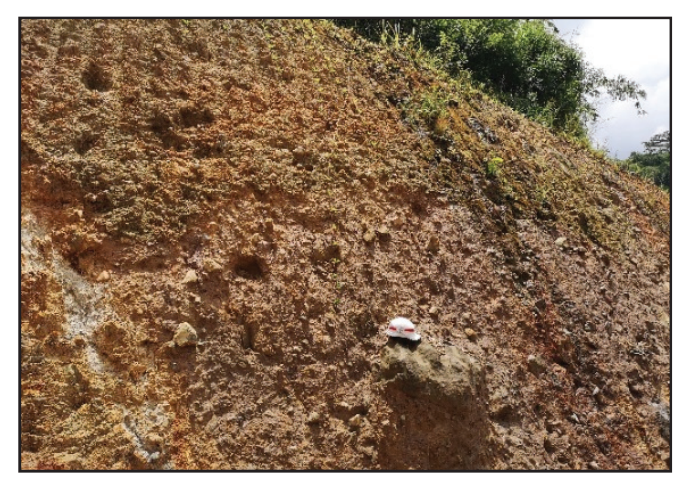

Fig. 6. Outcrop of volcanic breccia slightly weathered
Equation (5) obtained in this research is different from the empirical equation (2) proposed by Hoek and Brown [2] however, it has similarities with Zhang et al [11] empirical equation and when seen in Figure 9, the linear line of equation 5 is close to the linear line of the Ceballos and Olalla [3] equation

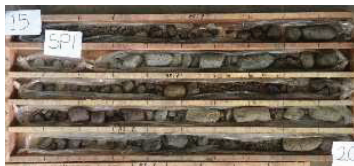

(a)

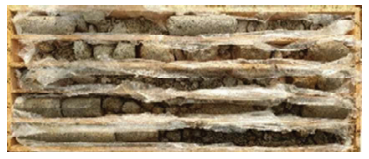

(c)

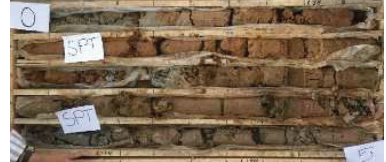

(b)

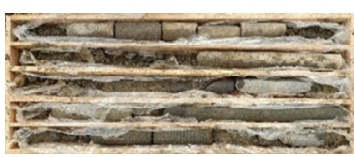

(d)
Fig. 7. Typical drill cores at the research location, material : (a) residual soil ; (b) lapilli tuf poor quality ; (c) lapilli tuf with moderate quality ; (d) volcanic breccia with moderate quality

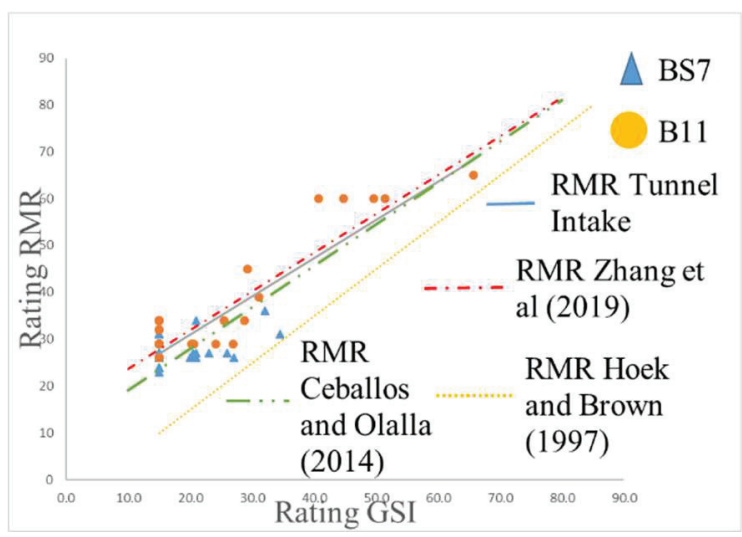

Fig. 8. The correlation equation between RMR $_{89}$ and GSI at the research location was compared with the correlation between RMR 89 and GSI Hoek and Brown [4], RMR and GSI Zhang et al [11] and RMR and GSI Ceballos and Ollala [3]

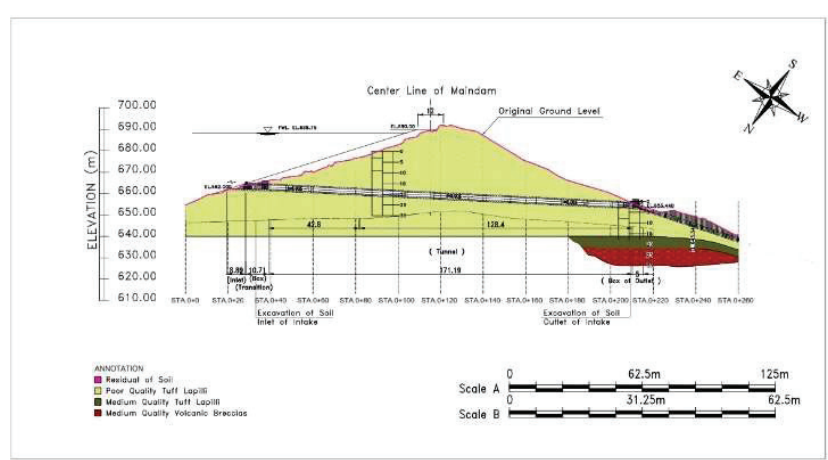

Fig. 9. Longitudinal section of engineering geological rock mass subsurface of the intake tunnel 
Table. 1. Engineering geological characteristics of the rock mass at the research area

\begin{tabular}{|c|c|}
\hline Lithology & Characteristics \\
\hline $\begin{array}{c}\text { Lapilli tuff } \\
\text { with poor } \\
\text { quality }\end{array}$ & $\begin{array}{l}\text { Brownish (moderately weathered) - } \\
\text { whitish (slightly weathered - fresh). } \\
\text { Medium grained - coarse. Good - } \\
\text { medium sorting, containing } \\
\text { fragments of rock fragments (litihik } \\
15 \% \text { ) with a size of } 2 \sim 64 \mathrm{~mm} \text {, } \\
\text { pumice, volcanic glass, } 10 \% \text { quartz } \\
\text { mineral, } 75 \% \text { dominant glass, } \\
\text { tapered mineral form. This lithology } \\
\text { has a moderate level of weathering, } \\
\text { GSI values } 15-27 \text { RMR } 24-31 \text {, } 25 \text { Mpa. Water } \\
\text { UCS ranges from } 1 \text { - } 25 \text { Mpa } \\
\text { content } 16.01 \% \text { dry density } 0.82 \text { gr } / \\
\mathrm{cm}^{3}\end{array}$ \\
\hline $\begin{array}{l}\text { Lapilli tuff } \\
\text { with } \\
\text { moderate } \\
\text { quality }\end{array}$ & $\begin{array}{l}\text { Brownish (moderately weathered) - } \\
\text { whitish (slightly weathered - fresh). } \\
\text { Medium grained - coarse. Good - } \\
\text { medium sorting, containing } \\
\text { fragments of rock fragments (lithik } \\
15 \% \text { ) with a size of } 2 \sim 64 \mathrm{~mm} \text {, } \\
\text { pumice, volcanic glass, } 10 \% \text { quartz } \\
\text { mineral, } 75 \% \text { dominant glass, } \\
\text { tapered mineral form. This lithology } \\
\text { has a slightly weathering level, GSI } \\
\text { values } 28-43 \mathrm{RMR} 8932-39 \text {, UCS } \\
\text { ranges from } 5-25 \mathrm{MPa} \text {. Water } \\
\text { content } 13.3 \% \text {, dry density } 1.17 \text { gr / } \\
\mathrm{cm}^{3}\end{array}$ \\
\hline $\begin{array}{l}\text { Volcanic } \\
\text { breccia } \\
\text { with } \\
\text { moderate } \\
\text { quality }\end{array}$ & 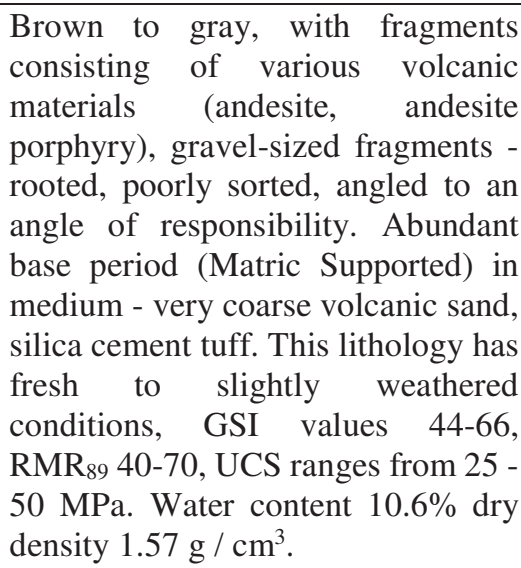 \\
\hline
\end{tabular}

The quality of rock mass in the research area can be divided into rock mass classes based on lithology and weathering. The quality of rock mass at the research location is divided into three, namely poor quality lapilli tuff $\left(\mathrm{RMR}_{89} 24\right.$ - 31), medium quality lapilli tuff (RMR 89 32 - 39), and medium quality volcanic breccias $\left(\mathrm{RMR}_{89} 40\right.$ - 70). The description of the characteristics of each rock mass engineering geological unit is shown in Table 1. In general, the rock mass in the research area has a mild to a high level of weathering. Whole-rock has a UCS value ranging from 1 to $50 \mathrm{MPa}$ and is extremely weak to medium-strong strength category. Figure 9 shows that the intake tunnel alignment is in poor quality tuff lapilli.

\section{Conclusions and Recommendations}

The research area consisted of lithology in the form of volcanic breccias and tuff lapilli. Rock masses have a mild to a high degree of weathering. Whole-rock has a UCS value ranging from 1 to $50 \mathrm{MPa}$ and is extremely weak to medium-strong strength category. The GSI value of the rock mass in the study area ranges from $15-65$, while the RMR value ranges from $24-70$. The intake tunnel is located in tuff lapilli rock with moderate weathering conditions.

The relationship between the GSI value and the RMR of rock mass in the research location can be expressed by equation 3 have results that are quite close to the research of Zhang et al [11].

Further research is needed, including determining the stability of the portal slope, the determination of the excavation method, and the tunnel support system based on the rock mass characterization results of this study.

Thank you very much to BBWS Bengawan Solo for research and supervising lecturers of Masters in Geological Engineering, Gadjah Mada University, so that this journal can be completed. We acknowledge PT. Waskita Karya (Persero) for the financial support for education and research through the super-specialist program held by PUPR in the year 2020.

\section{References}

1. PUSGEN, Indonesia earthquake source and hazard map (Peta sumber dan bahaya gempabumi Indonesia). Indonesia: Minister for Public Works and Housing (2017)

2. Z.T. Bieniawski, Engineering Rock Mass Classification, NewYork (1989)

3. F. Ceballos and C. Olalla, Relationship between RMRb and GSI based on in situ data. Technical University of Madrid, Spanyol (2014)

4. E. Hoek and E. T. Brown, Practical estimates of rock mass strength. International Journal of Rock Mechanics and Mining Sciences, 34,8: 1165-1186 (1997)

5. E. Hoek, T. G. Carter, M. S. Diederichs, Quantification of the geological strength index chart. US Rock Mechanics/Geomechanics Symposium, San Francisco (2013)

6. ISRM, Suggested methods for the quantitative description of discontinuities in rock masses: international cociety for rock mechanics. International Journal of Rock Mechanics and Mining 
Science and Geomechanics Abstracts, 15: 319-368 (1978)

7. P. Marinos and E. Hoek, GSI: a geologically friendly tool for rock mass strength estimation. International Society for Rock Mechanics and Rock Engineering (2000)

8. PT. Aditya, Studi Investigasi Tambahan Untuk DD Waduk Jlantah, Kartasura (2017) 